Article

\title{
The Role of Open Innovation and Value Co-creation in the Challenging Transition from Industry 4.0 to Society 5.0: Toward a Theoretical Framework
}

\author{
Barbara Aquilani $^{1}\left({ }^{1}\right.$, Michela Piccarozzi $^{1} * \mathbb{1}$, Tindara Abbate ${ }^{2}$ and Anna Codini ${ }^{3}$ \\ 1 Department of Economics, Engineering, Society and Business Organization (DEIM), 47, Via del Paradiso, \\ University of 'Tuscia', 01100 Viterbo, Italy; b.aquilani@unitus.it \\ 2 Department of Economics, 1, Piazza Pugliatti, University of Messina, 98122 Messina, Italy; abbatet@unime.it \\ 3 Department of Economics and Management, 74/b, Via S. Faustino, University of Brescia, 25122 Brescia, Italy; \\ anna.codini@unibs.it \\ * Correspondence: piccarozzi@unitus.it; Tel.: +39-0761-307506
}

Received: 6 October 2020; Accepted: 24 October 2020; Published: 28 October 2020

check for updates

\begin{abstract}
Advanced manufacturing solutions, augmented reality, and cloud and big data are technologies pertaining to Industry 4.0. These technologies improve working conditions, create new business models, and increase both productivity and firm quality production. However, they can also improve life and society as a whole. This new perspective, oriented toward social and global well-being, is called Society 5.0. As has happened for all past industrial revolutions, Industry 4.0 will support the transition to a different society, i.e., Society 5.0. In this transition, open innovation and value co-creation can play an important role. The aim of the study was twofold: to examine how Industry 4.0 features and enabling technologies can support the transition to Society 5.0 and to investigate the roles of both open innovation and value co-creation within this transition. A conceptual framework was developed to jointly consider for the first time Industry 4.0, Society 5.0, open innovation, and value co-creation, which are all challenging issues that firms must cope with nowadays. Managers could profit from these insights to design ad hoc strategies in order to benefit from the opportunities emerging from this transition and overcome the main related challenges.
\end{abstract}

Keywords: Industry 4.0; Society 5.0; open innovation; value co-creation; big data; artificial intelligence

\section{Introduction}

The Fourth Industrial Revolution, also called "Industry 4.0," has recently become a relevant phenomenon and one of the most internationally prominent topics in both industry and academia today [1-4]. Industry 4.0 can be understood as the combination of physical and digital technologies, such as artificial intelligence (AI), cloud computing, big data, adaptive robotics, augmented reality, additive manufacturing, and the Internet of things (IoT) [3]. It can be considered the core and the result of digital transformation in firms, especially in manufacturing activities [5]. Despite the opportunities originating from digitalization at each stage of the production and service systems, the management side of Industry 4.0 has not yet been studied in depth and its definition remains ambiguous, even if it has already been stated that Industry 4.0 must be considered as "the result of a purposely formulated strategy implemented over time" [4] (p. 16). Although its manufacturing basis is focused on new technologies [6], the next industrial revolution, Industry 4.0, will lead to both important changes in societies and the adaptation to changing environments [7]. Considering that firms are the locus of innovation within societies [8] and that innovation today is more and more often realized with individuals as part of a "human-centered" society, this is consistent with the concept of Society 5.0, which can "balance economic advancement with the resolution of social problems by 
a system that highly integrates cyberspace and physical space" [9]. Furthermore, as Society 5.0 can only come through data-driven innovation [10], the link between Industry 4.0 and Society 5.0 looks really tight. Indeed, Society 5.0 was proposed as the desired future society of Japan in the Fifth Science and Technology Basic Plan, where it "follows the hunting society (Society 1.0), agricultural society (Society 2.0), industrial society (Society 3.0), and information society (Society 4.0)" [11]. This "social reform," as can be read in the same document, "will achieve a forward-looking society that breaks down the existing sense of stagnation, a society whose members have mutual respect for each other, transcending generations, and a society in which each and every person can lead an active and enjoyable life" [11]. In this sense, it is clear that Industry 4.0 can greatly support the transition to Society 5.0, a society with sustainability at its core, thanks to its features and enabling technologies (i.e., big data, AI and IoT).

At the same time, firm innovation processes realized through open innovation (OI) following a value co-creation perspective can assume a strategic role in this transition, focusing on the opening and sharing of innovations between firms and society as a whole. Notwithstanding the close link between Industry 4.0 and Society 5.0 outlined above, this issue remains unexplored in the management literature, as is also the joint role of $\mathrm{OI}$ and value co-creation.

Therefore, the aim of the study was to explore two main research topics:

- how Industry 4.0 features and enabling technologies can support the transition to Society 5.0;

- the role of both OI and value co-creation within this transition.

However, there is another underlying issue related to these topics, namely, big data. Indeed, information and data play an essential role in each domain considered in this study and their role must be understood to fully explore the two main issues driving this study.

In this context, Fukuda [10], for example, claims that the advent of Society 5.0 is taking place thanks to data-driven innovation, while the Organization for Economic Co-operation and Development $(\mathrm{OECD})$ states that "big data, are becoming a core asset in science, technology and innovation ecosystem which enhances productivity, fosters new industries and create economic competitive advantages and social welfare benefits" [12] (p. 29).

Therefore, big data are both a key element of the new Society 5.0 and an essential enabling technology in order to run effective OI and value co-creation processes, e.g., just think of their role in the development of new products and services.

As a consequence, another topic needed to be investigated in this study, namely, the interplay between the mentioned models and big data and the reason why they are all necessary for the transition from Industry 4.0 to Society 5.0.

To explore the above-mentioned issues, this study examined the main contributions toward this transition, with a focus on Industry 4.0, the transition from Industry 4.0 to Society 5.0, the role of OI and value co-creation in this transition and big data, assuming a managerial perspective. Then, it puts forward a conceptual framework to understand how Industry 4.0 features and enabling technologies can support the transition to Society 5.0, what role both OI and value co-creation assume within this transition, and how big data might contribute to the achievement of Society 5.0.

Theoretical and managerial implications, as well as the limitations of this study and future avenues of research, are presented in the concluding section of this paper.

\section{Literature Review}

A systematic literature review is often used to present the state of the art of a quite recent topic and to suggest new avenues of research. However, this methodology requires the subject matter to have been studied for at least several years in order to understand, for example, which issues have already been studied by scholars and which are the main streams of literature that have already emerged. The most important aim in this methodology is to draw a clear picture of the subject matter and to identify the gaps in the literature that already exist in order to help scholars to further explore 
the subject matter. Even though some authors agree there is no minimum number of published papers that constitutes a systematic literature review $[13,14]$, it is also true that a systematic literature review considering only a few papers or only two years has not yet been published. Unfortunately, this is the case with the link between Industry 4.0 and Society 5.0. Indeed, from a search using the keywords "Industry 4.0" and "Society 5.0" in the Scopus database, the main resource in management studies [15], only 58 published documents appeared, which were reduced to only 6 documents using the methodological approach of Tranfield et al. [16] and limiting the selection to management, the domain in which this paper fall, and papers published in English referred journals [17] (please see Figure 1 and Table 1).

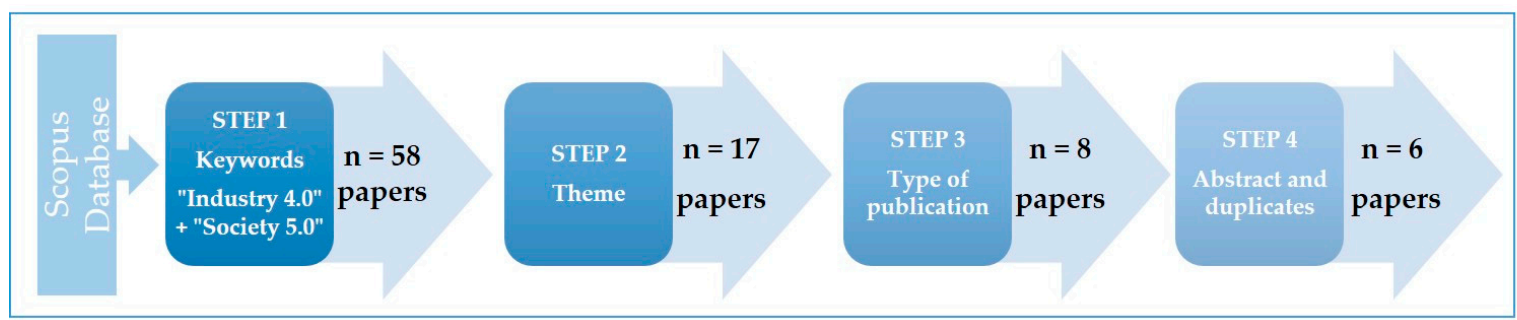

Figure 1. Systematic literature review process: "Industry 4.0 " and "Society 5.0". Our elaboration.

Table 1. Systematic literature review using "Industry 4.0" and "Society 5.0" keywords: paper details.

\begin{tabular}{|c|c|c|c|c|c|c|}
\hline Author & Title & Journal & Year & Vol. & Issue & Pag. \\
\hline $\begin{array}{l}\text { Potočan, V., Mulej, M., } \\
\text { and Nedelko, Z. }\end{array}$ & $\begin{array}{l}\text { Society } 5.0 \text { : balancing of } \\
\text { Industry } 4.0 \text {, economic } \\
\text { advancement and social } \\
\text { problems }\end{array}$ & Kybernetes & 2020 & Pre-print & Pre-print & Pre-print \\
\hline $\begin{array}{l}\text { Alvarez-Cedillo, J., } \\
\text { Aguilar-Fernandez, M., } \\
\text { Sandoval-Gomez R., Jr, } \\
\text { and Alvarez-Sanchez, T. }\end{array}$ & $\begin{array}{l}\text { Actions to Be Taken in } \\
\text { Mexico towards } \\
\text { Education } 4.0 \text { and } \\
\text { Society } 5.0\end{array}$ & $\begin{array}{l}\text { International } \\
\text { Journal of } \\
\text { Evaluation and } \\
\text { Research in } \\
\text { Education }\end{array}$ & 2019 & 8 & 4 & 693-698 \\
\hline Gladden, M.E. & $\begin{array}{c}\text { Who will be the } \\
\text { members of Society } 5.0 ? \\
\text { Towards an } \\
\text { anthropology of } \\
\text { technologically } \\
\text { posthumanized future } \\
\text { societies }\end{array}$ & Social Sciences & 2019 & 8 & 5 & $1-39$ \\
\hline $\begin{array}{l}\text { Melnyk, L.H., } \\
\text { Kubatko, O.V., } \\
\text { Dehtyarova, I.B., } \\
\text { Dehtiarova, I.B., } \\
\text { Matsenko, O.M., and } \\
\text { Rozhko, O.D. }\end{array}$ & $\begin{array}{l}\text { The effect of industrial } \\
\text { revolutions on the } \\
\text { transformation of social } \\
\text { and economic systems }\end{array}$ & $\begin{array}{l}\text { Problems and } \\
\text { Perspectives in } \\
\text { Management }\end{array}$ & 2019 & 17 & 4 & $381-391$ \\
\hline $\begin{array}{c}\text { Sulianta, F., Sapriya J., } \\
\text { Supriatnac, N., Disman D. }\end{array}$ & $\begin{array}{l}\text { Digital content model to } \\
\text { promote literacy in } \\
\text { society version } 5.0 \\
\text { using the social study } \\
\text { education perspective }\end{array}$ & $\begin{array}{l}\text { International } \\
\text { Journal of } \\
\text { Innovation, } \\
\text { Creativity and } \\
\text { Change }\end{array}$ & 2019 & 6 & 12 & - \\
\hline Riminucci, M. & $\begin{array}{c}\text { Industry } 4.0 \text { and } \\
\text { Human Resources } \\
\text { Development: A View } \\
\text { from Japan }\end{array}$ & $\begin{array}{l}\text { E-Journal of } \\
\text { International and } \\
\text { Comparative } \\
\text { Labour Studies }\end{array}$ & 2018 & 71 & 1 & $1-15$ \\
\hline
\end{tabular}

Our elaboration.

Moreover, the other combinations of keywords (keywords "Society 5.0" and "open innovation") returned no documents (please see Figure 2), and the keywords "Society 5.0" and "value co-creation" 
returned no documents (please see Figure 3) that were able to identify any contributions that establish the state of the art of the subject matter studied in this paper.

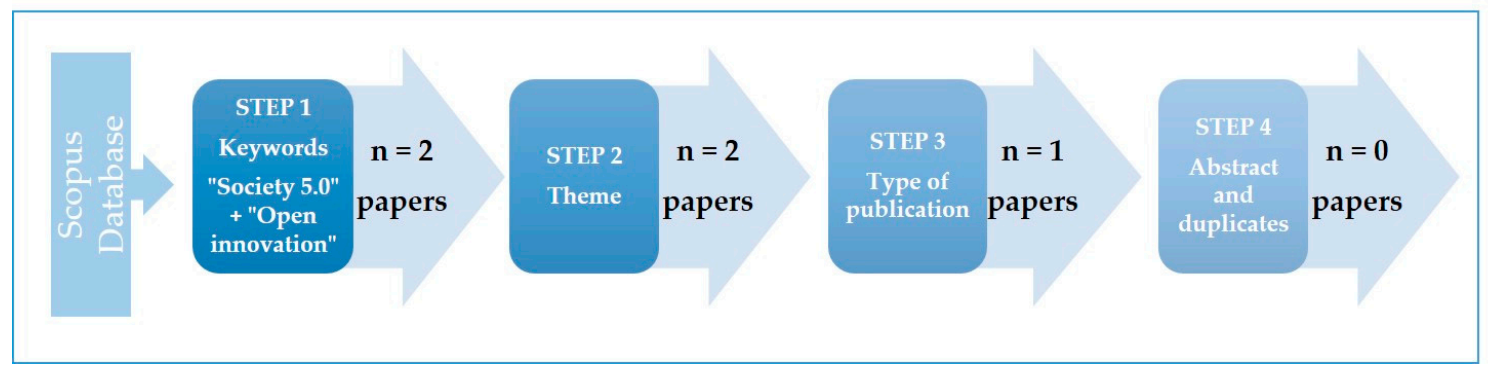

Figure 2. Systematic literature review process using "Society 5.0" and "open innovation." Our elaboration.

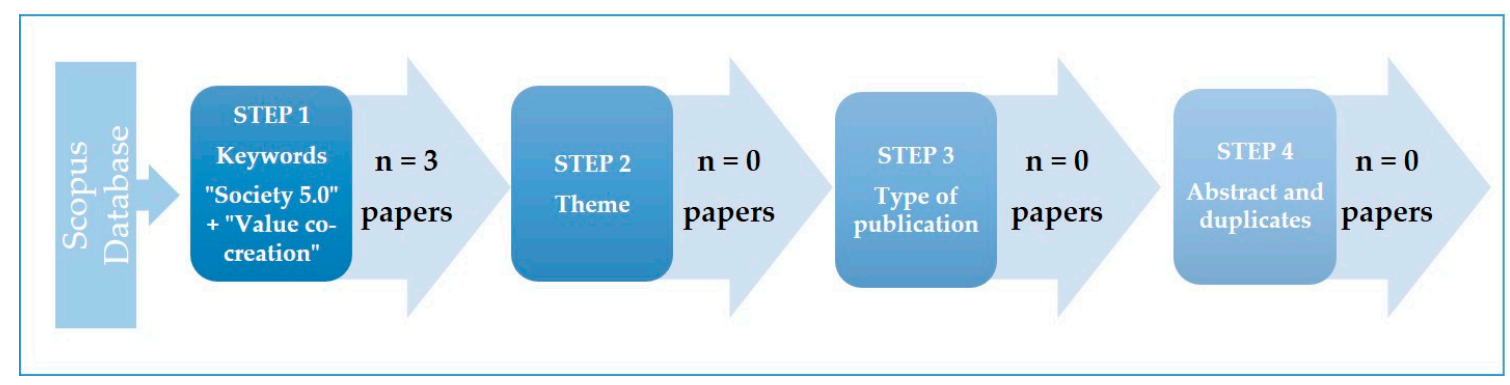

Figure 3. Systematic literature review process using "Society 5.0" and "value co-creation." Our elaboration.

This is not surprising given that it is only in the last two years that scholars have begun to investigate Society 5.0. Given the few papers available using the systematic review approach, our search for contributions on this subject was widened to sources other than English international referred journals to encompass conferences, white papers, etc., that were able to help us identify at least some of Society 5.0's essential features, as well as the links with Industry 4.0, OI, and value co-creation. In this domain, it is also worth noticing that to publish in referred journals, authors undergo a refereeing process, which takes time such that contributions on new subjects usually appear in these outlets with some delays.

Therefore, this literature review does not follow a "traditional" systematic literature review approach, even if it encompasses all the papers retrieved with the methodology summarized in Figures 1-3 above.

The analysis of the literature was divided into several sections to identify the relationships between the various topics analyzed (Industry 4.0, the link between Industry 4.0 and Society 5.0, OI, value co-creation, and big data).

\subsection{Industry 4.0: Some Essential Insights}

Only recently has a definition of Industry 4.0 in the management domain been established that includes all relevant elements appearing in the literature and highlights the role of strategy for this transition to new production methods that dramatically change firm business models. It underlines that "Industry 4.0 refers to the integration of Internet of Things technologies into industrial value creation enabling manufacturers to harness entirely digitized, connected, smart, and decentralized value chains" [6] (p. 423) that can "deliver greater flexibility and robustness to firm competitiveness and enable them to build flexible and adaptable business structures, [acquiring] the permanent ability for internal evolutionary developments in order to cope with a changing business environment" [7] (p. 583). Additionally, Industry 4.0 can be observed "as the result of a purposely formulated strategy 
implemented over time" [4] (p. 16). From this definition, it emerges that innovations resulting from the Fourth Industrial Revolution have profoundly influenced firm strategies and operations, which at the moment is almost always with reference to technical aspects. Indeed, the areas most affected by the introduction of innovations pertaining to Industry 4.0 are growth and employment $[10,18]$, though, at the same time, there are positive results regarding productivity, investments, and efficiency in terms of business processes [19]. However, in recent literature, some threats linked to Industry 4.0 have emerged, such as the expected job reduction highlighted by Birkel et al. [20], even if, at this stage, the debate is still wide open considering that the digital transformation is ongoing and it follows diverse paths in different countries, industries, and firms. Taking a picture of Industry 4.0 management literature today, it is possible to identify various aspects and/or issues that have already been studied, such as production methods, business models [21-23], strategy [24-26], impact and outcomes of Industry 4.0 [27-29], human resources [30-32], effects on small-to-medium enterprises (SMEs) [33-35], the supply chain [36-38], sustainability [6,39,40], information systems [41], and social innovation [42]. However, in none of the retrieved studies did the main research question involve investigating how Industry 4.0 will reshape societies, with the exception of some papers that examined the consequences of Industry 4.0 for firms, such as the impact of value creation [2] or its benefits [29], such as firm flexibility, demand orientation, sustainability, automated knowledge, learning, and productivity optimization. Another element that emerges from the literature is the analysis of Industry 4.0 enabling technologies. Indeed, many authors [43-45] have investigated the Industry 4.0 set of technologies and, although various classifications were proposed, the most used by scholars are those provided by Rüßmann et al. [19] and Brunelli et al. [46].

The authors identified nine enabling technologies in the Industry 4.0 domain: advanced manufacturing, additive manufacturing, augmented reality, simulation, horizontal/vertical integration, IoT, the cloud, cyber-security, and big data. Furthermore, AI can also be added to this list in that it is considered "essential to clearly define its structure, methodologies and challenges as a framework for its implementation in industry" [47] (p. 20). Finally, it is worth noticing that, besides the above-mentioned enabling technologies, the "human side" of the organization cannot be neglected as it benefits from the innovations and advantages of Industry 4.0 [48].

\subsection{From Industry 4.0 to Society 5.0}

Industry 4.0, as briefly described above, represents the main driver of innovation within firms in recent years. However, firms by their nature are the locus of innovation for societies [8], while Society 5.0, as already underlined, needs data-driven innovation to be realized [10].

It is clear that, as has happened in the past, in this case, a different kind of society should emerge from Industry 4.0, with the proposed Society 5.0 being a clear consequence. In particular, in the proposed future Society 5.0, Japan, which defines its strategy to guide technological innovation processes, has decided to put technological innovation in the spotlight based on the fact that it can be fully considered as a tool for social innovation and not just a factor leading to changes in firms and business processes. In this way, it has been clearly stated that technological innovation plays an essential role in realizing the transition to Society 5.0.

The Japanese Government has not adopted the term Industry 4.0 due to considering these new technologies too simplistic to impact the pillars of Japanese society but has chosen the term "super-smart society" and stated that Society 5.0 will be achieved through it [49].

Society 5.0 can be considered the philosophical response promoted by Keidanren, the powerful Japanese Industrial Association, to the German concept of Industry 4.0 [50].

The term Society 5.0 was first used in the Fifth Science and Technology Basic Plan [51], which is a program whose aim is to connect physical space (the real world) and cyberspace, taking advantage of all the potential of new technologies in order to achieve an ideal future society.

Mavrodieva and Shaw [52] define Society 5.0 as "similar to Industry 4.0 but [it] takes a step forward, depicting a data-driven economy and society-a Super Smart Society, with a focus on individual needs 
and capabilities. The concept envisages a merge between the real (physical) world with the cyberspace in order to efficiently collect more precise and personalized data for improved problem solving and value creation" (p. 3). In this future society, individual and/or organizational needs would be accurately identified and satisfied by providing all the required top-quality products and services in the required amount at exactly the required time [49]. For the Japanese Government, IoT, AI, robotics, and other enabling technologies, which all pertain to Industry 4.0, will radically change social structures and industrial features.

Therefore, their role must be considered essential in the transition to Society 5.0, which "has its roots in Japanese culture and managerial thought, but presents significant innovations: it is a process that must be carried out together with citizens who are required to actively participate and, therefore, not just top-down; recognizes and underlines the importance of creating less formal relationships between people, businesses, universities and the Public Administration; highlights the need to develop a more intense collaboration with foreign people and firms, which bring in technological knowledge of the frontier" [49] (p. 53).

When analyzing this definition, several elements emerge: (a) the primary role of managerial thought; (b) the active role of citizens, considered as individuals; (c) the need for less informal relationships within society as a whole, whether individuals pertain to firms and/or otherwise; (d) the need for collaboration; (e) the need to develop new technological knowledge through collaboration. The elements emerging from the definition recall the collaboration and the involvement of several subjects in the realization of the transition from Industry 4.0 to Society 5.0 (i.e., citizens or the society as a whole); in this domain, from a managerial point of view, the involvement of OI and value co-creation processes can be seen (please see infra).

The first insight supports the consideration that the transition to Society 5.0 must be planned, organized, and managed, putting the managerial strategy to be formulated and implemented at the very core of its success; this will be the first step for a successful transition, i.e., step (a) above.

This matches perfectly with the new definition given for Industry 4.0, which considers that Industry 4.0 needs an ad hoc strategy [4] and clarifies that the transition from Industry 4.0 or the super-smart society [49] to Society 5.0 is the expected result of efforts made by all involved firms and organizations sharing the same vision of a different society. However, linked to this are other insights coming from the definition of Society 5.0, which all depend on the active role of individuals (step (b)) who are the only ones able to build and run less informal relationships (step (c)) and who can enable collaboration (step (d)) that also leads to new technological knowledge (step (e)).

However, various scholars have recently raised some concerns about individuals in Society 5.0, such as Gladden [53], who identified six different types of participants, namely, "natural, biological human beings," "artificially augmented human beings," "metahuman beings," "epihuman beings," "parabeing humans," and "nonhuman beings," all of which are to be involved in the future Society 5.0, though not all of them have been considered real individuals as part of society until now, especially when considering the last two above-mentioned categories. More extremely in this sense is the claim of Nurullin [54], who defines Society 5.0 as a "self-devouring system." Indeed, Society 5.0 suggests "to solve global problems of civilization by expanding the civilizational benefits," (p. 1) which inevitably leads to the postponement of the ineluctable end of humanity, and in this way, would disintegrate the whole system of humanity.

However, all authors agree that individuals are the key for shaping the future society; the same focus which drives value co-creation and which justifies why individuals or participants are so important when speaking of Society 5.0 as well as firm contributions to it.

The latter even more frequently use some practices (e.g., co-creation) focusing on individual participation in firm activities, while others have completely reshaped their business model around them, where their consideration is essential for managing each aspect of the firm's activities and to understand which firm contributions could help with building a new society. Indeed, individuals must be put at the very core of each aspect of the future society and must be supported by firms, which are 
obviously embedded in managerial thought. Firms, however, have already developed various approaches to enhance collaboration; OI (e.g., [55]), for example, is able to create new knowledge, not only at a technological level. Moreover, value co-creation following a strategic approach (e.g., [56]), which encompasses some OI processes, e.g., interactive coupled ones, is deemed to support the transition to Society 5.0 in that it is based solely on individuals and their active role. For this reason, it seems essential to look more in depth at the potential contribution of OI and value co-creation processes in the transition from Industry 4.0 to Society 5.0 given that Industry 4.0 will contribute to Society 5.0 , just as Society 5.0 needs Industry 4.0 to be realized.

\subsection{Open Innovation in the Transition from Industry 4.0 to Society 5.0}

OI is based on the assumption that a single organization today has difficulty innovating alone; the best resources are not always within the firm [57].

To be successful in its primary function, i.e., innovation [58], engagement with a variety of partners is necessary to acquire input and resources from outside the firm to remain competitive $[57,59,60]$. OI can be understood as "a distributed innovation process based on purposively managed knowledge flows across organizational boundaries, using pecuniary and non-pecuniary mechanisms in line with the organization's business model" [61] (p. 27). Therefore, OI emphasizes "that firms can and should use external ideas as well as internal ideas, and internal and external paths to market, as they look to advance their technology" [59] (p. 2). This allows firms to reshape their architecture and systems [59].

Nowadays, OI is a well-known model that is widely investigated in the literature, which seems really suited to support the dynamics of Industry 4.0 described above, with its basis being knowledge exchange and innovation supported by technology. Indeed, OI diffusion was widely supported by information and communication technology (ICT), e.g., just think of OI intermediary online platforms able to connect people and/or firms and/or organizations for collaboration all over the world [62,63]. Moreover, an OI system at an international level is recognized as the locus in which platforms and technologies pertaining to Society 5.0 can develop [39].

Industry 4.0 innovations foster the diffusion of $\mathrm{OI}$ in that they allow the sharing of knowledge, resources, innovations, etc., with multiple partners, thanks to an increasing number of new features and more effective, complex, and rapid enabling technologies. Therefore, for the development of Industry 4.0 and Society 5.0, the OI approach is of outstanding importance [64].

In this domain, Fukuda [10] analyzed the role of OI in the transition to Society 5.0, underlining the importance of collaboration and ecosystem creation for the mutual exchange of innovations, as well as focusing on the role of big data (please see Section 2.5 for more details).

The author states that "the public and private sectors will have to work together to create the right environment for growth, focusing on labor market frameworks, entrepreneurship, competition, and talent and skills development, as well as the safety and regulations regarding data sharing. These efforts could maximize the benefits of data-driven innovation and revitalize its productivity and growth in Society 5.0" (p. 13). In this way, OI processes assume a central role in that they are based solely on collaborations between different actors in the domain of innovation, which is, per se, essential to the transition to Society 5.0. Indeed, Salgues [65] directly investigated innovation in Society 5.0, stating that it must be characterized by "innovations in service $[\ldots$,$] open innovation and frugal$ innovation" (p. 157). Further support of the essential role of OI in the transition to Society 5.0 was also provided by Timonina [66], who states that "in the context of building the Society 5.0-a super smart society, what becomes prioritized are such directions of scientific-technical and innovation policy as the consolidation of efforts of business, government, and academia, a more active use of the potential of university science on the principles of "open innovation", the commercialization of research results conducted by universities, and the development of innovative entrepreneurship in the form of startups and ventures" (p. 93).

What clearly emerges from the above is that OI processes must be initiated and run not only among firms and/or organizations but among a plethora of actors who can and must all contribute to 
make the new Society 5.0 a reality; a plethora of actors that was envisaged right from the first definition of OI [67]. OI as a different approach to innovation brings these actors together and generates, through its processes, the collaboration needed to foster innovation in all organizations, as well as having collaborating actors generating the premise and the initial step toward the new Society 5.0.

\subsection{Value Co-creation in the Transition from Industry 4.0 to Society 5.0}

Whether all OI processes (inbound, outbound, or coupled [68]), involve individuals within firms and/or other institutions, only coupled interactive processes lead to value co-creation $[69,70]$.

Value co-creation, therefore, must be seen as a "view start[ing] with interactions as the locus of value[, where] platforms of engagements with individuals are the locus of value creation, and co-creative enterprises follow a single principle: they focus their entire organization on the engagements with individuals" [71] (p. 11). Interactions are the locus of value [71] and the focus is on individuals and human experiences (e.g., [56]). Each individual thus co-creates value connected to all other individuals collaborating in co-creation processes, not just together and/or on behalf of the individual firm [72].

Value co-creation becomes a "win more-win more" approach that expands to "wealth-welfarewellbeing all around," where "co-creatively leveraging all stakeholder capabilities in meshwork of social, business, civic, and natural communities can lead to better states of governance, infrastructure, development, and sustainability" [56] (p. 31). From this statement, the tight link between value co-creation and the future Society 5.0 appears clear. Indeed, value co-creation processes, realized through interactions, such as that suggested by the definition of Society 5.0 , affect the transition to this society.

However, value co-creation expands beyond the single domain in which interactions take place, enhancing the ecosystem of capabilities [56] and in this way, the entire society in which individuals live and operate. Indeed, "the process of value creation [ ... ] shifted from independent to interactive, from close to open, from stable to dynamic," and in this way, the science, technology, and innovation ecosystem shifted "from a push-based system to a pull-based system" that is able to bring "value source from the inside and outside of the system" [15] (p. 13). In this domain, it is easy to recognize the primary and active role of individuals and the creation of less informal relationships that develop into interactions, while individuals collaborate in engagement platforms sharing, enhancing, and creating ever new resources, knowledge, etc.

All values created and shared between participating individuals simultaneously $[70,73]$ and all the insights of the definition of Society 5.0 (please see Section 2.2) can be found in this managerial approach called value co-creation. Therefore, value co-creation can be considered the approach to be used to build Society 5.0. Value co-creation processes by individuals will bring great innovations at every level, and above all, new and varied experiences to both firms and society as a whole, nurturing it toward being more human-centered.

In other words, if firms are the locus of innovation for societies [8], it would appear that they have already adopted a human-centered way of innovating and achieving success through value co-creation processes. Indeed, firms already involved will be the first engine to start the shift of societies toward Society 5.0 as a result of firms developing newer technologies based on individual desires and expectations. Following the aforementioned considerations, it can be said that even if value co-creation can be interpreted as the managerial approach that is deemed to achieve Society 5.0, OI processes run by firms and/or other organizations involving individuals can also support this shift, not only per se but also because they foster innovation in all domains, including those encompassed in Industry 4.0, which in turn help to enhance OI processes through its features and enabling technologies.

To identify this virtuous mechanism in which various areas of society (firms, environment, and society in general) are integrated, Kaihara used the term "systems of systems" [74]; the "systems of systems" nurture never-ending value co-creation processes to realize a super-smart society. Indeed, the link between value co-creation and Society 5.0 is enabled by "inclusivity," which represents "the first step [of] the co-creation strategy" [75] (p. 3), and at the same time, the first principle of Society 5.0 [52]. 
The inclusivity of the entire society, supported by the enabling technologies of Industry 4.0, allows the improvement toward Society 5.0 that "will be a Creative Society, where digital transformation combines with the imagination and creativity of diverse people to solve social problems and create value. In Society 5.0, humans will exercise imagination not only for themselves, but also for nature and technology to seek ways of achieving symbiosis with them" [76] (p. 8).

Data, or rather, big data are of paramount importance to achieve this aim. Indeed, as Unoura [77] states: "we will promote the creation of an environment for integrating, opening up, and utilizing data across sectors based on a new ecosystem to accelerate the realization of Society 5.0" (p. 7); it can easily be supposed that this new ecosystem is the ecosystem of capabilities, which is one of the pillars, together with the engagement platforms and the domain of experiences [78], of the value co-creation strategic approach.

\subsection{Big Data: Some Essential Insights}

Big data is an abstract concept [79], and over the years, numerous definitions have been proposed for it [80-82]. However, the most cited and shared definition is the one proposed by Laney [80], which suggests a threefold explanation, thus encompassing the "three Vs" that characterize big data: volume, variety, and velocity. The first important feature of the definition is the volume of data generated. From 2000 to today, the amount of stored data has increased exponentially [83], e.g., just think of the volume of information gathered every day on social media (e.g., Facebook and Twitter). The growth of the data volume is closely linked to the never-ending use of newer and newer advanced technologies (e.g., smartphones, PCs, devices, and smart TVs). Variety refers to how the boundless use of these new technologies, sensors, and smart devices has multiplied the assortment of data available to firms. Big data, therefore, include both traditional information and "raw, semi structured, and unstructured data from web pages, web log files (including click-stream data), search indexes, social media forums, e-mails, documents, sensor data from active and passive systems, and so on" [83] (p. 7).

Velocity is closely related to the first two. In fact, firms today have to manage a huge amount of data of exceptional variety, which needs to be extracted and elaborated more and more rapidly.

The amount of big data increases continuously, leading to the need for its continuous production, in that big data are very often made of real-time data providing instantaneous indications that can change rapidly, which can therefore be used successfully only at a given moment [83].

This definition has since been reiterated by the National Institute of Standards and Technology (NIST) [84] and Beyer and Leyner [85] and further expanded by IBM [86] to include a fourth V, namely, veracity. Buhl et al. [87] (p. 68) affirm that big data "are a multidisciplinary and evolutionary fusion of new technologies in combination with new dimensions in data storage and processing (volume and velocity), a new era of data source variety (variety) and the challenge of managing data quality adequately (veracity)." The latter encompasses the issues of trust and uncertainty regarding both data and the outcome of its analysis. Veracity considers some key aspects of data, in particular: confidentiality, integrity, and availability [88], and highlights the importance of data quality [86].

Big data concerning consumers are not always accurate; thus, veracity becomes even more important when the other three Vs are all constantly increasing [89]. In this context, Saha and Srivastava [90] underline how, given the volume, variety, and velocity of data collection and production, poor quality and false data can quickly be disseminated.

For this reason, the fourth characteristic of big data, namely, veracity, becomes fundamental in order to have concrete and truthful data; it is, therefore, necessary to understand and possibly repair incorrect data in a scalable and timely manner [90].

This shows why big data is so important in the application of Industry 4.0 innovations [91] and, in particular, in the new firm business model definition [87].

Big data are, in fact, produced by all firms, organizations, and individuals at every moment of their lives and are obviously produced when OI and value co-creation processes are run, almost certainly thanks to online platforms. Surely, they are of paramount importance in making the best decisions for 
firms when considering the abovementioned processes and, in this context, it is also clear that big data analytics are essential for leading innovation [15].

However, firms must be equipped with new datasets that span different contexts [92,93] to profit from this opportunity. At the same time, by extracting and elaborating upon big data, firms can enhance their knowledge of various issues, providing this data is truthful. Indeed, in this case, data are not always collected thanks to the "owners," but are generated through all activities carried out almost always using technological tools by individuals; this is why privacy issues are even more important nowadays and why institutions act directly regarding protection (e.g., new rules about privacy have recently been issued by the European Parliament).

Going beyond the definition of big data and their paramount importance for firms, what is clear to scholars is that the rise of big data paves the way for newer and greater opportunities that not only have an economic impact but also have impacts at the social level and in the domain of everyone's ways of living and thinking [79]. They can be considered as "a core asset in [science, technology and innovation] ecosystem which enhances productivity, fosters new industries and create economic competitive advantages and social welfare benefits" [15] (p. 9).

In the domain of the transition to Society 5.0, big data represent an important fulcrum [10,12,77,94,95], together with other Industry 4.0 enabling technologies (e.g., AI and IoT).

Indeed, as Pu and Yano [94] state: "in Society 5.0, a huge amount of information from sensors in physical space is accumulated in cyberspace. In cyberspace, Big Data is analysed by artificial intelligence (AI), and the analysis results are fed back to humans in physical space in various forms [ ..., where] the IoT (Internet of Things) provides a crucial link between cyberspace and physical space" (p. 21). Therefore, big data, along with AI and IoT, represent the enabling technology that gives concrete input to the transition from Industry 4.0 to Society 5.0; in fact, "big data collected by IoT will be converted into a new type of intelligence by AI and will provide solutions for improved human lives" [95] (p. 4).

Furthermore, big data are of paramount importance in the OI domain in that "the characteristics of Big Data match positively with the principles of open innovation" [96] (p. 10), and for firms, it is essential to use and manage big data to acquire knowledge and skills to implement innovation strategies, as well as OI $[59,97]$. The use of big data, therefore, provides significant benefits in terms of OI through the creation of an open business model, in the management and analysis of markets, and finally in managing organizational changes and increasingly turning to innovation [96].

Big data, however, are also essential in value co-creation processes. Indeed, Xie et al. [98] stated that "big data is transformed from resources into cooperative assets in value co-creation processes" (p. 1046). Moreover, Troisi et al. [99] assumed that firms and consumers can co-create value by combining different information deriving from big data; the consumers' big data can be combined by firms on digital platforms and contribute to co-creating value using OI rules and features.

Therefore, big data, among the Industry 4.0 enabling technologies, represent the "starting point" in order to begin the transfer of knowledge, resources, etc., and innovate from cyberspace to the physical space of firms and society in general, shaping the innovation processes following the OI approach [59] and involving a plethora of actors through engagement platforms by nurturing the ecosystem of capabilities and enhancing the domain of experiences, which creates a never-ending process toward a better society. Therefore, big data, following this perspective, can be understood as the main vehicle for transferring information and innovation and progressively building a better society, using OI and value co-creation as "enabling mechanisms" in order to achieve this aim $[96,98]$.

\section{The Framework}

\subsection{Basic Foundations of the Model}

The theoretical framework proposed for the transition from Industry 4.0 to Society 5.0 is presented in Figure 4. It encompasses OI and value co-creation, without neglecting the role of big data, among other 
enabling technologies (AI and IoT). In addition, the framework is focused on the role of firms in the transition from Industry 4.0 to Society 5.0 because this transition certainly represents a pressing challenge for them and they are the locus of innovation in society [8].

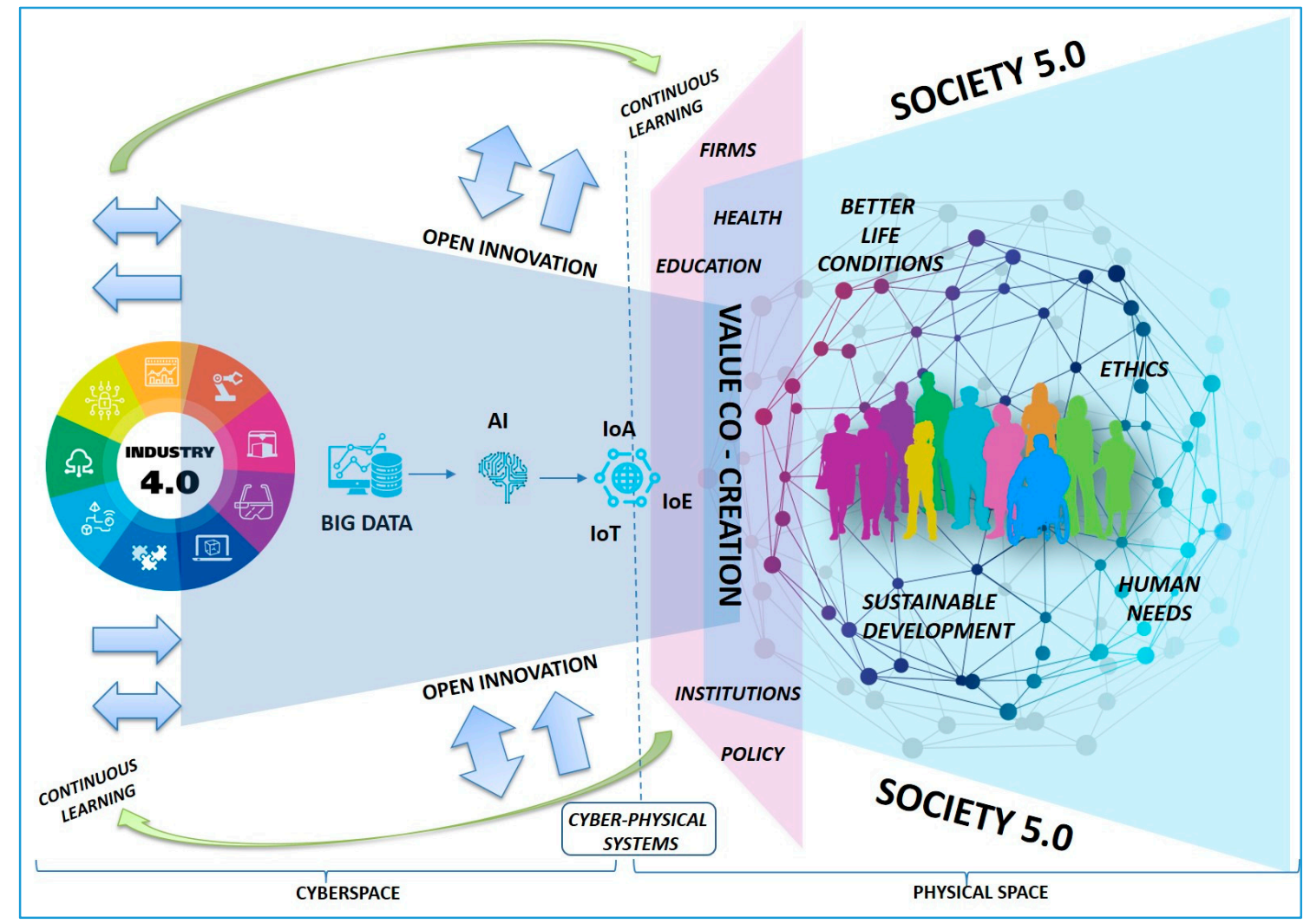

Figure 4. The challenging transition from Industry 4.0 to Society 5.0 from a firm's standpoint. Our elaboration. AI: artificial intelligence, IoA: Internet of abilities, IoE: Internet of everything, IoT: Internet of things.

The model is divided into two macro areas: cyberspace and physical space.

The area on the left refers to cyberspace, which is a typical environment of Industry 4.0 innovations, where the various enabling technologies that are useful for the transition to Society 5.0 are located (in particular big data, as already mentioned) [100]. In the area on the right-hand side of the figure, there is physical space, which is the real space in which firms (in part) and society as a whole, as well as individuals, operate [101].

This division into two areas means understanding how enabling technologies, beginning with big data, through the intervention of $\mathrm{AI}$ and IoT, allow for the conversion of information into concrete interventions on society in general, thus passing from a purely virtual environment (cyberspace) to a real and everyday life environment (physical space). In this view, IoT represents the concrete link between cyberspace and physical space [94], and in particular, it operates in the so-called cyber-physical systems (CPS) domain [102].

Indeed, as Ochoa et al. [103] (p. 1) state: "advances in wireless communication, in computing and in sensing devices, along with the cost reduction of these technologies, have prompted and accelerated the development of Cyber-Physical Systems".

CPS represent an evolution of cyberspace that facilitates the integration of different and physically distant subjects such that IoT is placed at the center of the model as a link between cyber and physical space, operating concretely in the context of CPS [104]. 
Coming back to the other components of the model, in the transition to Society 5.0, the link between AI and IoT is very close; this is witnessed by the term "Internet of abilities" (IoA) [105], which was created by some authors to identify it.

The IoA can be defined as the "abilities in both human capability and AI capability [which] can be made transferrable, interconnectable, and work synergistically" [76] (p. 6).

Strictly linked to IoA is the concept of the Internet of Everything (IoE), which was recently proposed by scholars. Indeed, the IoE considers four fundamental pillars: people, data, processes, and things [106], where the involvement of people and their skills are expressed by IoA as its foundation. IoE has a broader scope than IoT and supports organizations, for example, in achieving public policy goals, environmental sustainability, economic, and social goals [107].

IoT, therefore, represents the central enabling technology of the proposed model and its subsequent extensions (i.e., IoA and IoE) that contribute to making it even more effective and useful for the transition from Industry 4.0 to Society 5.0.

In this context, an important role is also played by continuous learning and the education system.

Continuous learning helps with equipping all generations with even newer skills, which are necessary in the new vision of society; this is an issue that has already been pointed out by both some authors (e.g., [52]) and the Japanese government itself [108]. While the education system represents the "starting point" of continuous learning about the enabling technologies of Industry 4.0, it also provides the enabling mechanisms that are necessary to support the transition from Industry 4.0 to Society 5.0. Therefore, the educational system and continuous learning that involve learning about both enabling technologies and mechanisms are essential for making the transition to Society 5.0 concrete.

In addition, from Figure 4, it is clear that the proposed framework is made up of three different but closely intertwined parts.

The first one, on the left, represents the firm; the second, on the right, represents individuals within society; the central part is where firms and individuals cooperate in activities that are not carried out just on behalf of firms' goals. Firms today are even more open to external collaboration, whether from other firms, research centers, professionals, individuals, communities, etc. (please see Section 2.3).

For this reason, firm boundaries have become porous and permeable [109] and allow OI to develop following various processes (inbound, outbound, and coupled [68]), where these are represented by the arrows for inbound, outbound, and coupled processes not leading to co-creation, while for coupled OI processes leading to co-creation, a special part of the figure, at the very center, has been created.

This clarifies that benefits coming from value co-creation are shared with individuals participating in firm activities (please see Section 2.4), as well as part of society.

Some firms innovate in the Industry 4.0 domain and rarely alone, thanks to collaboration (this is made clear with the round Industry 4.0 positioned on the left of the pale blue square that is partially inside and partially outside firm boundaries), while Industry 4.0 features and enabling technologies are used by almost all firms, even if each of them follows its own path in the digital transformation.

\subsection{Processes and Model Operating Mechanisms}

The core of the model is the enabling technologies of Industry 4.0, which make the transition to Society 5.0 possible.

Entering into the details of the functioning of the model, it is possible to observe that the most used enabling technologies in this domain are IoT (and its extensions, i.e., IoA and IoE) and AI in that they enable efficient and effective OI processes that are fundamental to business operations (indicated in the pale blue square in the figure).

Besides these, big data deserves a special mention in that it provides all the background information firms need for their decision-making processes. Additionally, big data, as already observed (see Section 2.5), combined with the use of enabling technologies, such as digital platforms (represented in the figure as a rose parallelogram), enable interactive, coupled OI processes that lead to value co-creation. In this domain, it is true that individuals can participate in OI processes within communities 
and that they can collaborate not only with firms but also with institutions as individuals or as part of communities, or only within individual communities in order to achieve special purposes (e.g., some kind of charity association).

All these activities, not including firms, are represented by the tight links between individuals in the pale green square on the right-hand side of the figure, excluding those in the parallelogram representing the shared space with firms. Indeed, co-creation and/or OI processes can also be run by other organizations (not directly by firms) involving individuals, and in this case, the domain in which the transition to Society 5.0 is more evident is in policy, health, etc. However, also in this case, it is true that almost all innovations enabling these processes come from firm innovation processes (e.g., digital platforms).

Thus, firms support the transition from Industry 4.0 to Society 5.0 not only per se or directly but also because they provide and support all other actors, such as institutions, individuals, and communities, in their OI and/or value co-creation processes, even if the results of these activities do not generate immediate benefits for them or do not involve them. However, emerging needs to be met and even new requests from individuals who are more involved and demanding of profits from enabling technologies and solutions spur firms to start innovation processes or enhance existing ones to create the premise for other interactions, innovations, etc., which easily go on to nurture the Industry 4.0 toolbox.

All these enabling technologies gradually become instruments for "everyday usage" by firms, individuals, institutions, etc., and support the ongoing transition at every level to Society 5.0. Big data in the individual domain enhances the human experiences of involved individuals who nurture the entire society, progressively transforming it into a different model, namely, Society 5.0. Obviously, in this future society, individuals aspire to better living conditions and today are more and more aware of the importance of sustainable development in a scenario where human needs are always present but where individuals expect much more in respect to the past because technology can support them in newer ways (e.g., an exoskeleton).

Moreover, individuals alone or as part of communities can create engagement platforms; sometimes it is the firm that joins an existing platform and starts to co-create with individuals participating in it [70].

However, institutions can create digital platforms in which they co-create by taking advantage of the thoughtful and enthusiastic participation of individuals and apply it to policy, health, etc. They are part of the Society 5.0 square on the right of the figure (these processes are not the focus of the study, which is on firms, but it is necessary to consider their existence, even though they are not studied at length). Only when firms are included, it is necessary to consult the parallelogram, where all participants can play a part in the co-created value and value co-creation following a strategic approach is carried out. Moreover, institutions can create ad hoc digital platforms to help firms in their innovation processes (i.e., [110]) and in this way contribute, at a certain moment, to ameliorate some aspects of individual lives in that firms are the locus of innovation in all industries of society. In this framework, individuals are thus at the very core because they enable interactions, which in turn, are the basis for both OI and value co-creation processes. Therefore, they will play a pivotal role above all if individuals are to be considered in the transition from Industry 4.0 to a Society 5.0 that includes "parabeing humans" and "nonhuman beings" [53], and thus would be guided exclusively, especially the latter, by AI.

This insight, even though it is of great interest, is still a thing of the future, which is to be studied in-depth after further development of such individuals. For this reason, this study could not shed more light on this specific issue.

\section{Discussion}

These first insights regarding the proposed framework help to investigate the three research topics underlying this study. 


\subsection{The Most Suited Technologies for the Transition from Industry 4.0 to Society 5.0}

The most important Industry 4.0 technologies for the transition to the new Society 5.0 must certainly be big data, IoT (with its extensions IoA and IoE), and AI, which together provide all the initiating and sharing information processes.

In Society 5.0, AI will convert big data into a new widespread type of intelligence and IoT will allow for this transfer and use it within society. Life will be more sustainable and comfortable as only desired products and services will be provided as required. These enabling technologies become essential to initiate OI processes, both more easily and rapidly, as well as value co-creation among all individuals [111,112].

Thus, big data and these enabling technologies will be of paramount importance (please see the third research topic answer infra), while digital platforms will probably grow, given they sustain interactions between individuals.

Big data characteristically provide more effective and rapid interactions and will undoubtedly benefit from Industry 4.0 innovations. Indeed, Industry-4.0 enabling technologies nurture each other and they all, following various combinations, help run OI and value co-creation processes, which in turn, nurtures innovation in the domain of Industry 4.0.

Moreover, AI represents another essential enabling technology in the transition between Industry 4.0 and Society 5.0 in that, as already stated, it allows for the re-elaboration of information collected through big data.

At the same time, AI supports the diffusion of OI in firms by creating virtuous circles between individuals direct learning from external people and autonomous learning generated thanks to AI and then used by firms in their strategic decision-making process [113]. Furthermore, AI is closely linked to the co-creation of value as it allows for the numerous instances of "human-to-non-human resource integration" that are essential to run and carry out all the value co-creation processes [114] to be understood and explained.

Finally, IoT represents the concrete means for the transition to Society 5.0, the technology with which the results produced using big data are organized and disseminated with OI thanks to AI and are then transferred to the society as a whole through value co-creation processes.

Therefore, IoT is the enabling technology that permits the passage from cyberspace to the real world, clarifying the results obtained by the application of Industry-4.0 enabling technologies through the enabling mechanisms (i.e., OI and value co-creation) in order to achieve Society 5.0.

Indeed, as Mejtoft [115] affirms: the "Internet of Things makes it possible to incorporate and interact with customers in any phase of the value creation process. This is a prerequisite for a value centered design process of future products and services. A common view on co-creation is that value is created by collaboration, facilitated by technology (like the Internet), between people" (p. 673).

In the proposed framework, more complex technologies have been envisaged, such as AI nurtured by big data, such that data not only comes from customers regarding products and services created by firms but also data coming from individuals using these enabling technologies and enabling mechanisms (i.e., OI and value co-creation) to build a better society.

\subsection{The Role of OI and Value Co-creation within This Transition}

Value co-creation, in general, together with interactive, coupled OI processes, are the pillars supporting the transition from Industry 4.0 to Society 5.0, or rather the essential "enabling mechanisms." OI processes have already evolved, beginning with the most studied and used inbound ones [116,117], followed by outbound ones, which are more profitable [118], then coupled ones, which pave the way to value co-creation. OI differs greatly from the closed innovation model, which was the only one known about fifteen years ago [116,119]. New technologies are clearly essential within this evolution and will continue to play an increasingly important role. However, the true innovation of co-creation, as well as Industry 4.0 and Society 5.0, is the different general approaches to individuals and their true value, both for firms and society. Given that firms create innovation within society, OI has clearly encouraged 
the development of synergies and joint results, and can therefore be considered the first enabling mechanism in the transition from Industry 4.0 to Society 5.0. Value co-creation, on the one hand, has made the role of individuals clear. It is now evident that individuals can not only successfully contribute to innovation in firms but also to society in increasingly innovative ways, given the twofold link that clearly exists today. Moreover, it can be said that through value co-creation processes, new insights, ideas, etc., are exchanged between firms and society in new and more rapid ways, creating a virtuous circle between innovation in firms and better conditions of life in society, where the real engine of this virtuous mechanism are the individuals supported by the enabling technologies of Industry 4.0.

Therefore, it can be said that OI processes, when not leading to value co-creation, contribute to the transition from Industry 4.0 to Society 5.0 in an almost indirect way through innovations realized by firms thanks to these processes, while value co-creation directly affects this transition.

Indeed, value co-creation can be understood as the other essential enabling mechanism through which individuals, obviously supported by ever newer technologies, contribute to the transition to Society 5.0; individuals themselves contribute to enabling technology development by being engaged in value co-creation processes that can affect society as a whole through innovation. Moreover, they start and/or participate in every value co-creation process that is developing within all sectors of society, directly contributing to building the desired society.

\subsection{The Interplay between the Mentioned Models and Big Data and the Reason Why They Are All Necessary for the Transition from Industry 4.0 to Society 5.0}

The development and success of the model aimed at achieving the objectives of Society 5.0 depend on big data. McAfee et al. [120] (p. 2) state that “you can't manage what you don't measure. [... ] Data-driven decisions are better decisions. Using Big Data enables managers to decide on the basis of evidence rather than intuition. For that reason, it has the potential to revolutionize management".

Big data are an increasingly important engine to better understand the complex system of OI, even if firms must invest to be ready to fully profit from it through datasets that are able to span different domains [92].

Moreover, the generated data potentially enable firms to access previously unavailable information and, when elaborated, support even more firms' strategies and operations and innovation processes, as well as value co-creation processes, which can profit from them, and at the same time, nurture them. Following this thought, it seems that big data can be considered the necessary fuel to run OI and value co-creation processes, contributing to innovation in the domain of Industry 4.0 and enabling a more rapid and successful transition to Society 5.0.

In the proposed model, big data represent the starting point, the enabling technology of Industry 4.0 on which the transition to Society 5.0 is based. Indeed, without big data, there could be no conjunction between cyberspace and physical space made concrete by AI, and above all, IoT [94,95]. At the same time, it would not be possible to implement OI processes, and consequently value co-creation for firms and for society as a whole, without reliable data [99], which must be correctly collected, elaborated, and made available through the IoT.

\section{Conclusions}

This paper sought to draw an initial picture of the more effective elements for the transition from Industry 4.0 to Society 5.0, putting forward a conceptual model in a domain that is still unexplored by the management literature. In doing so, it offers both theoretical and managerial contributions. Initially, the most important is to offer various useful insights into realizing the difficult transformation from Industry 4.0 to Society 5.0, thanks to managerial thoughts and approaches that are already known and successfully applied by firms.

The paper started by reviewing the literature at the intersection of OI, value co-creation, and Industry 4.0, embracing a new approach that is focused on individuals desiring a better society 
and aware that technologies and enabling mechanisms already used in firms can greatly help build better societies. Indeed, combining different streams of literature, as yet not fully studied, provided an initial insight into how firms might be considered the necessary engine to create better societies.

Obviously, firms would now seek benefits and new and/or different opportunities from the past and should also be aware that various and/or unknown threats could emerge that need to be managed and/or avoided.

Further studies are therefore necessary to identify the drivers of future strategic decision-making processes and understand why only some of them could emerge as essential. New/different trade-offs and challenges must also be met, e.g., just think of the challenges linked to the nature of various kinds of individuals to be considered as participants in OI and value co-creation processes.

From a managerial perspective, this paper provides managers with a more comprehensive picture of possible options and pitfalls within a changing context. It provides a clearer link to the challenges that may appear and greater awareness of their links and mutual relationships.

Thanks to the proposed model, firms may become aware of different individual needs and requests that do not come directly from the relationship with the firm but instead from the aspiration to build a different society; this can not only greatly help firms design better OI and value co-creation processes but also distribute their resources and build infrastructures, e.g., digital platforms, that are needed to support activities with individuals. In this way, firms may have the opportunity to find new and/or different ways to co-create value and share it with engaged individuals such that the benefits received are precisely those they desire and expect from their collaboration. Moreover, firms might also consider that "participants" in Society 5.0 may not be individuals as we understand them but also "automated" participants who must also be involved.

This is a really challenging issue that is neither considered by most firms nor by managers, where new organizational issues also emerge. Moreover, this paper highlights the big data issue, which could be even more important in the future for firms that presently do not perceive exactly why they are so important, and above all, sooner or later, all firms must be equipped to deal with them, profiting from their potential to enhance decision-making processes and avoid at least some of the risks.

This paper also provides an understanding of the combined action of various Industry-4.0enabling technologies for the transition to Society 5.0 through defining the role of big data, AI, and IoT, as well as understanding the essential link between cyberspace and the real world. At the same time, it clarifies how the above-mentioned enabling technologies can use enabling mechanisms, such as OI and value co-creation processes, to foster innovation at all levels, not only in firms but for society as a whole in order to achieve Society 5.0.

Notwithstanding the original traits of the paper and its implications, both theoretical and managerial, it is important to point out that it presents some limitations. In particular, the main one is the lack of an empirical test of the theoretical model proposed through one or more case studies. This limitation also provides, among others, further possible investigation.

Moreover, it could also be interesting to perform a cross-sectional analysis that seeks to understand whether there are any geographical and/or industrial differences in implementing OI and value co-creation processes, whilst being aware of the potential contribution to Society 5.0. Moreover, future conceptual studies are required to better develop the proposed framework, which also takes into account non-human participants in the transition to Society 5.0.

Author Contributions: All authors have contributed to the conceptualization, while writing-review and editing was divided as follows: M.P.: Section 1, Section 2.1, and Section 2.5; B.A. and M.P.: Section 2.2, Section 3, and Section 4; T.A. and B.A.: Section 2.4; T.A. and A.C.: Section 2.3; all authors contributed to Section 5. All authors have read and agreed to the published version of the manuscript.

Funding: This research received no external funding.

Acknowledgments: The authors would like to greatly thank the editors for their support and reviewers for their thoughtful and really interesting suggestions and comments, which have been extremely useful for enhancing this paper. 
Conflicts of Interest: The authors declare no conflict of interest.

\section{References}

1. Bahrin, M.A.K.; Othman, M.F.; Azli, N.H.N.; Talib, M.F. Industry 4.0: A review on industrial automation and robotic. J. Teknol. 2016, 78, 6-13.

2. Roblek, V.; Meško, M.; Krapež, A. A complex view of Industry 4.0. SAGE Open 2016, 6. [CrossRef]

3. Ustundag, A.; Cevikcan, E. Industry 4.0: Managing the Digital Transformation; Springer: Berlin/Heidelberg, Germany, 2017.

4. Piccarozzi, M.; Aquilani, B.; Gatti, C. Industry 4.0 in management studies: A systematic literature review. Sustainability 2018, 10, 3821. [CrossRef]

5. Beltrametti, L.; Guarnacci, N. La fabbrica Connessa. La Manifattura Italiana (Attra)Verso Industria 4.0; goWare e Edizioni Angelo Guerini e Associati, Ed.; Guerini e Associati: Milan, Italy, 2014; ISBN 8862506988.

6. Prause, G.; Atari, S. On sustainable production networks for Industry 4.0. Entrep. Sustain. Issues 2017, 4, 421-431. [CrossRef]

7. Koether, R. (Ed.) Taschenbuch der Logistik; Carl Hanser Verlag GmbH Co KG.: Munich, Germany, 2018.

8. Pitelis, C.N.; Teece, D.J. The (new) nature and essence of the firm. Eur. Manag. Rev. 2009, 6, 5-15. [CrossRef]

9. Federation, K.J.B. Toward Realization of the New Economy and Society-Reform of the Economy and Society by the Deepening of "Society 5.0"; 2016. Available online: https://www.keidanren.or.jp/en/policy/2016/029_ outline.pdf (accessed on 18 October 2020).

10. Fukuda, K. Science, technology and innovation ecosystem transformation toward society 5.0. Int. J. Prod. Econ. 2020, 220, 107460. [CrossRef]

11. Cabinet Office. Society 5.0. Available online: https://www8.cao.go.jp/cstp/english/society5_0/index.html\#: \{\{\}: text=Social\%20reform\%20(innovation)\%20in\%20Society, an\%20active\%20and\%20enjoyable\%20life (accessed on 12 May 2020).

12. OECD. Data-Driven Innovation; OECD: Paris, France, 2015; ISBN 9789264229341.

13. Kapoor, P.; Kharbanda, O.P.; Monga, N.; Miglani, R.; Kapila, S. Effect of orthodontic forces on cytokine and receptor levels in gingival crevicular fluid: A systematic review. Prog. Orthod. 2014, 15, 65. [CrossRef] [PubMed]

14. Fisch, C.; Block, J. Six tips for your (systematic) literature review in business and management research. Manag. Rev. Q. 2018, 68, 103-106. [CrossRef]

15. Abatecola, G.; Mandarelli, G.; Poggesi, S. The personality factor: How top management teams make decisions. A literature review. J. Manag. Gov. 2013, 17, 1073-1100. [CrossRef]

16. Tranfield, D.; Denyer, D.; Smart, P. Towards a methodology for developing evidence-informed management knowledge by means of systematic review. Br. J. Manag. 2003, 14, 207-222. [CrossRef]

17. Newbert, S.L. Empirical research on the resource-based view of the firm: An assessment and suggestions for future research. Strateg. Manag. J. 2007, 28, 121-146. [CrossRef]

18. Schwab, K. The Fourth Industrial Revolution; Penguin Books Ltd.: London, UK, 2016; ISBN 0241300754.

19. Rüßmann, M.; Lorenz, M.; Gerbert, P.; Waldner, M.; Justus, J.; Engel, P.; Harnisch, M. Industry 4.0: The Future of Productivity and Growth in Manufacturing Industries; Boston Consulting Group: Boston, MA, USA, 2015; pp. 54-89.

20. Birkel, H.; Veile, J.; Müller, J.; Hartmann, E.; Voigt, K.-I. Development of a risk framework for industry 4.0 in the context of sustainability for established manufacturers. Sustainability 2019, 11, 384. [CrossRef]

21. Berawi, M.A. Utilizing big data in industry 4.0: Managing competitive advantages and business ethics. Int. J. Technol. 2018, 9, 430. [CrossRef]

22. Gerlitz, L. Design management as a domain of smart and sustainable enterprise: Business modelling for innovation and smart growth in Industry 4.0. Entrep. Sustain. Issues 2016, 3, 244-268. [CrossRef]

23. Bressanelli, G.; Adrodegari, F.; Perona, M.; Saccani, N. Exploring how usage-focused business models enable circular economy through digital technologies. Sustainability 2018, 10, 639. [CrossRef]

24. Maier, M.A.; Korbel, J.J.; Brem, A. Innovation in supply chains-solving the agency dilemma in supply networks by using industry 4.0 technologies. Int. J. Commun. Netw. Distrib. Syst. 2015, 15, 235. [CrossRef]

25. Wahl, M. Strategic factor analysis for industry 4.0. J. Secur. Sustain. Issues 2015, 5, 241-247. [CrossRef]

26. Müller, J.M.; Kiel, D.; Voigt, K.I. What drives the implementation of Industry 4.0? The role of opportunities and challenges in the context of sustainability. Sustainability 2018, 10, 247. [CrossRef] 
27. Liao, Y.; Deschamps, F.; de Loures, E.F.R.; Ramos, L.F.P. Past, present and future of Industry 4.0—A systematic literature review and research agenda proposal. Int. J. Prod. Res. 2017, 55, 3609-3629. [CrossRef]

28. Rodič, B. Industry 4.0 and the new simulation modelling paradigm. Organizacija 2017, 50, 193-207. [CrossRef]

29. Sener, E.; Yuksel, A.N. The reflections of digitalization at organizational level: Industry 4.0 in Turkey. Pressacademia 2017, 6, 291-300.

30. Bonekamp, L.; Sure, M. Consequences of Industry 4.0 on human labour and work organisation. J. Bus. Media Psychol. 2015, 6, 33-40.

31. Kovacs, G.; Kot, S. New logistics and production trends as the effect of global economy changes. Polish J. Manag. Stud. 2016, 14, 115-126. [CrossRef]

32. Kinzel, H. Industry 4.0-Where does this leave the Human Factor? J. Urban Cult. Res. 2017, 15, 70-83.

33. Sommer, L. Industrial revolution-industry 4.0: Are German manufacturing SMEs the first victims of this revolution? J. Ind. Eng. Manag. 2015, 8, 1512-1532. [CrossRef]

34. Ganzarain, J.; Errasti, N. Three stage maturity model in SME's toward industry 4.0. J. Ind. Eng. Manag. 2016, 9, 1119. [CrossRef]

35. Shin, D.-I. An exploratory study of innovation strategies of the internet of things SMEs in South Korea. Asia Pac. J. Innov. Entrep. 2017, 11, 171-189. [CrossRef]

36. Barata, J.; Rupino Da Cunha, P.; Stal, J. Mobile supply chain management in the Industry 4.0 era. J. Enterp. Inf. Manag. 2018, 31, 173-192. [CrossRef]

37. Alekseev, A.N.; Evdokimov, S.Y.; Tarasova, A.Y.; Khachaturyan, K.S.; Khachaturyan, A.A. Financial strategy of development of industry 4.0 in the countries with developing economy. Rev. Espac. 2018, 39, 1-8.

38. Glas, A.H.; Kleemann, F.C. The Impact of Industry 4.0 on procurement and supply management: A conceptual and qualitative analysis. Int. J. Bus. Manag. Invent. 2016, 5, 55-66.

39. Pan, M.; Sikorski, J.; Kastner, C.A.; Akroyd, J.; Mosbach, S.; Lau, R.; Kraft, M. Applying industry 4.0 to the Jurong Island eco-industrial park. Energy Procedia 2015, 75, 1536-1541. [CrossRef]

40. Prause, G. Sustainable business models and structures for Industry 4.0. J. Secur. Sustain. Issues 2015, 5. [CrossRef]

41. Theorin, A.; Bengtsson, K.; Provost, J.; Lieder, M.; Johnsson, C.; Lundholm, T.; Lennartson, B. An event-driven manufacturing information system architecture for Industry 4.0. Int. J. Prod. Res. 2017, 55, 1297-1311. [CrossRef]

42. Morrar, R.; Arman, H.; Mousa, S. The fourth industrial revolution (Industry 4.0): A social innovation perspective. Technol. Innov. Manag. Rev. 2017, 7, 12-20. [CrossRef]

43. Büchi, G.; Cugno, M.; Castagnoli, R. Smart factory performance and Industry 4.0. Technol. Forecast. Soc. Chang. 2020, 150, 119790. [CrossRef]

44. Wan, J.; Cai, H.; Zhou, K. Industrie 4.0: Enabling technologies. In Proceedings of the 2015 International Conference on Intelligent Computing and Internet of Things, Harbin, China, 17-18 January 2015; IEEE: Piscataway, NJ, USA, 2015; pp. 135-140.

45. Kinsy, M.; Khan, O.; Celanovic, I.; Majstorovic, D.; Celanovic, N.; Devadas, S. Time-predictable computer architecture for cyber-physical systems: Digital emulation of power electronics systems. In Proceedings of the 2011 IEEE 32nd Real-Time Systems Symposium, Vienna, Austria, 29 November-2 December 2011; IEEE: Piscataway, NJ, USA, 2011; pp. 305-316.

46. Brunelli, J.; Lukic, V.; Milon, T.; Tantardini, M. Five Lessons from the Frontlines of Industry 4.0.; The Boston Consulting Group: Boston, MA, USA, 2017.

47. Lee, J.; Davari, H.; Singh, J.; Pandhare, V. Industrial artificial intelligence for industry 4.0-based manufacturing systems. Manuf. Lett. 2018, 18, 20-23. [CrossRef]

48. Alcácer, V.; Cruz-Machado, V. Scanning the Industry 4.0: A literature review on technologies for manufacturing systems. Eng. Sci. Technol. Int. J. 2019, 22, 899-919. [CrossRef]

49. Salvatore, G. Da Industria 4.0 a Società 5.0; 2018. Available online: https://www.academia.edu/35809134/Da_ Industria_4_0_a_Societ\%C3\%A0_5_0_La_scelta_del_Giappone (accessed on 12 May 2020).

50. Stefano, C. Il Giappone Alza la Posta: Rotta Verso la Società 5.0; Il Sole24Ore; 2017. Available online: https: //www.ilsole24ore.com/art/il-giappone-alza-posta-rotta-la-societa-50-AEdJyJZC (accessed on 13 March 2020).

51. Council for Science, Technology and InnovationCabinet Office, Government of Japan. Report on the 5th Science and Technology Basic Plan. 2015. Available online: https://www8.cao.go.jp/cstp/kihonkeikaku/ 5basicplan_en.pdf (accessed on 12 May 2020).

52. Mavrodieva, A.V.; Shaw, R. Disaster and climate change issues in japan's society 5.0—A discussion. Sustainability 2020, 12, 1893. [CrossRef] 
53. Gladden, M.E. Who will be the members of Society 5.0? Towards an anthropology of technologically posthumanized future societies. Soc. Sci. 2019, 8, 148. [CrossRef]

54. Nurullin, R.A. Society 5.0: A self-devouring system. Int. J. Recent Technol. Eng. 2019, 8, 4001-4004.

55. Chesbrough, H.W. The era of open innovation. MIT Sloan Manag. Rev. 2003, 44, 35-41.

56. Ramaswamy, V.; Ozcan, K. The Co-Creation Paradigm; Stanford University Press: Stanford, CA, USA, 2014; ISBN 978-0-8047-9075-8.

57. Dahlander, L.; Gann, D.M. How open is innovation? Res. Policy 2010, 39, 699-709. [CrossRef]

58. Von Hippel, E. Democratizing Innovation; MIT: Cambridge, MA, USA, 2005; ISBN 9780262002745.

59. Chesbrough, H.W. Open Innovation: A new paradigm for understanding industrial innovation. In Open Innovation: Researching a New Paradigm; Chesbrough, H., Vanhaverbeke, W., West, J., Eds.; Oxford University Press: Oxford, UK, 2006; pp. 1-12.

60. Laursen, K.; Salter, A. Open for innovation: The role of openness in explaining innovation performance among U.K. manufacturing firms. Strateg. Manag. J. 2006, 27, 131-150. [CrossRef]

61. Chesbrough, H.; Bogers, M. Explicating open innovation: Clarifying an emerging paradigm for understanding innovation. In New Frontiers in Open Innovation; Oxford University Press: Oxford, UK, 2014; pp. 3-28.

62. Aquilani, B.; Abbate, T.; Dominici, G. Choosing open innovation intermediaries through their web-based platforms. Int. J. Digit. Account. Res. 2016, 16. [CrossRef]

63. De Falco, S.E.; Renzi, A.; Orlando, B.; Cucari, N. Open collaborative innovation and digital platforms. Prod. Plan. Control 2017, 28, 1344-1353. [CrossRef]

64. Lasi, H.; Fettke, P.; Kemper, H.-G.; Feld, T.; Hoffmann, M. Industrie 4.0. Wirtschaftsinformatik 2014, 56, $261-264$. [CrossRef]

65. Salgues, B. Innovation in Society 5.0. In Society 5.0; John Wiley \& Sons, Inc.: Hoboken, NJ, USA, 2018; pp. 157-169.

66. Timonina, I.L. University startups and ventures and the competitiveness of the country: Experience of Japan. In Japanese Studies in Russia; Russian acad sciences inst far eastern studies, 32; Nakhimovsky Av: Moscow, Russia, 2018; pp. 92-110.

67. Chesbrough, H.W. Open Innovation: The New Imperative for Creating and Profiting from Technology; Harvard Business School Press: Boston, MA, USA, 2003.

68. Enkel, E.; Gassmann, O.; Chesbrough, H. Open R\&D and open innovation: Exploring the phenomenon. RED Manag. 2009, 39, 311-316.

69. Piller, F.; West, J. Firms, users, and innovation. In New Frontiers in Open Innovation; Oxford University Press: Oxford, UK, 2014; Volume 29, pp. 29-49.

70. Barbara, A. La Co-Creazione di Valore Nei Processi di Innovazione Aperta: Verso un Modello di Analisi; Cedam: Rome, Italy, 2016.

71. Leavy, B. Venkat ramaswamy-How value co-creation with stakeholders is transformative for producers, consumers and society. Strateg. Leadersh. 2014, 42, 9-16. [CrossRef]

72. Ind, N.; Iglesias, O.; Schultz, M. Building brands together: Emergence and outcomes of co-creation. Calif. Manage. Rev. 2013, 55, 5-26. [CrossRef]

73. Denning, S. An economy of access is opening for business: Five strategies for success. Strateg. Leadersh. 2014, 42, 14-21. [CrossRef]

74. Kaihara, T.S.K. System of systems concept and super smart society. J. SICE 2016, 55, 288-290.

75. Dollinger, M.; Lodge, J.M. Co-creation strategies for learning analytics. In Proceedings of the International Conference on Learning Analytics and Knowledge, Sydney, NSW, Australia, 7-9 March 2018; ACM: New York, NY, USA, 2018; pp. 97-101.

76. Federation, J.B. Society 5.0-Co-Creating the Future; Keidanren: Tokyo, Japan, 2018.

77. Unoura, H. Co-creating a virtuous cycle of new value. NTT Tech. Rev. 2018, 16, 1-7.

78. Aquilani, B.; Silvestri, C.; Ioppolo, G.; Ruggieri, A. The challenging transition to bio-economies: Towards a new framework integrating corporate sustainability and value co-creation. J. Clean. Prod. 2018, 172, 4001-4009.

79. Chen, M.; Mao, S.; Liu, Y. Big data: A survey. Mob. Netw. Appl. 2014, 19, 171-209. [CrossRef]

80. Laney, D. 3D data management: Controlling data volume, velocity and variety. Meta Gr. Res. Note 2001, 6, 2-13.

81. Manyika, J. Big Data: The Next Frontier for Innovation, Competition, and Productivity; McKinsey Global Institute: Washington, DC, USA, 2011. 
82. Oreilly, T. Big Data Now; O’Reilly Media, Inc.: Sebastopol, CA, USA, 2011.

83. Zikopoulos, P.; Eaton, C. Understanding Big Data: Analytics for Enterprise Class Hadoop and Streaming Data; McGraw-Hill Company: New York, NY, USA, 2015; ISBN 00717905359780071790536.

84. The National Institute of Standards and Technology (NIST). Big Data Working Group (NBD-WG); 2011. Available online: https://bigdatawg.nist.gov/home.php (accessed on 12 May 2020).

85. Beyer, M.A.; Laney, D. The Importance of "Big Data": A Definition. 2012. Available online: https://www.gartner. com/doc/2057415 (accessed on 12 May 2020).

86. IBM. What is Big Data?-Bringing Big Data to the Enterprise; IBM: Armonk, NY, USA, 2014.

87. Buhl, H.U.; Röglinger, M.; Moser, F.; Heidemann, J. Big data. Bus. Inf. Syst. Eng. 2013, 5, 65-69. [CrossRef]

88. Kepner, J.; Gadepally, V.; Michaleas, P.; Schear, N.; Varia, M.; Yerukhimovich, A.; Cunningham, R.K. Computing on masked data: A high performance method for improving big data veracity. In Proceedings of the 2014 IEEE High Performance Extreme Computing Conference (HPEC), Waltham, MA, USA, 9-11 September 2014; IEEE: Piscataway, NJ, USA, 2014; pp. 1-6.

89. Erevelles, S.; Fukawa, N.; Swayne, L. Big data consumer analytics and the transformation of marketing. J. Bus. Res. 2016, 69, 897-904. [CrossRef]

90. Saha, B.; Srivastava, D. Data quality: The other face of big data. In Proceedings of the 2014 IEEE 30th International Conference on Data Engineering, Chicago, IL, USA, 31 March-4 April 2014; IEEE: Piscataway, NJ, USA, 2014; pp. 1294-1297.

91. Gokalp, M.O.; Kayabay, K.; Akyol, M.A.; Eren, P.E.K. Big data for industry 4.0: A conceptual framework. In Proceedings of the International Conference on Computational Science and Computational Intelligence, Las Vegas, NV, USA, 15-17 December 2016; IEEE: Piscataway, NJ, USA, 2016; pp. 431-434.

92. Brunswicker, S.; Bertino, E.; Matei, S. Big data for open digital innovation-A research roadmap. Big Data Res. 2015, 2, 53-58. [CrossRef]

93. Kusiak, A. Smart manufacturing must embrace big data. Nature 2017, 544, 23-25. [CrossRef]

94. Pu, S.; Yano, M. Market quality approach to IoT data on blockchain big data. In Blockchain and Crypto Currency; Springer: Berlin/Heidelberg, Germany, 2020; pp. 21-40.

95. Sharp, L. Society 5.0: A brave new world. Impact 2020, 2020, 2-3. [CrossRef]

96. Del Vecchio, P.; Di Minin, A.; Petruzzelli, A.M.; Panniello, U.; Pirri, S. Big data for open innovation in SMEs and large corporations: Trends, opportunities, and challenges. Creat. Innov. Manag. 2018, 27, 6-22. [CrossRef]

97. Gatignon, H.; Tushman, M.L.; Smith, W.; Anderson, P. A structural approach to assessing innovation: Construct development of innovation locus, type, and characteristics. Manag. Sci. 2002, 48, 1103-1122. [CrossRef]

98. Xie, K.; Wu, Y.; Xiao, J.; Hu, Q. Value co-creation between firms and customers: The role of big data-based cooperative assets. Inf. Manag. 2016, 53, 1034-1048. [CrossRef]

99. Troisi, O.; D’Arco, M.; Loia, F.; Maione, G. Big data management. Int. J. Eng. Bus. Manag. 2018, 10, 184797901876777. [CrossRef]

100. Saldivar, A.A.F.; Li, Y.; Chen, W.N.; Zhan, Z.H.; Zhang, J.; Chen, L.Y. Industry 4.0 with cyber-physical integration: A design and manufacture perspective. In Proceedings of the In 2015 21st international conference on automation and computing (ICAC), Glasgow, UK, 11-12 September 2015; IEEE: Piscataway, NJ, USA, 2015; pp. 1-6.

101. Vaidya, S.; Ambad, P.; Bhosle, S. Industry 4.0—A glimpse. Procedia Manuf. 2018, 20, 233-238. [CrossRef]

102. Xu, H.; Yu, W.; Griffith, D.; Golmie, N. A survey on industrial internet of things: A cyber-physical systems perspective. IEEE Access 2018, 6, 78238-78259. [CrossRef]

103. Ochoa, S.F.; Fortino, G.; Di Fatta, G. Cyber-physical systems, internet of things and big data. Futur. Gener. Comput. Syst. 2017, 75, 82-84. [CrossRef]

104. Jazdi, N. Cyber physical systems in the context of Industry 4.0. In Proceedings of the 2014 IEEE International Conference on Automation, Quality and Testing, Robotics, Cluj-Napoca, Romania, 22-24 May 2014; IEEE: Piscataway, NJ, USA, 2014; pp. 1-4.

105. Rekimoto, J. Internet of abilities: Human augmentation, and beyond (keynote). In Proceedings of the 2017 IEEE Symposium on 3D User Interfaces (3DUI), Los Angeles, CA, USA, 18-19 March 2017.

106. Miraz, M.H.; Ali, M.; Excell, P.S.; Picking, R. A review on Internet of Things (IoT), Internet of Everything (IoE) and Internet of Nano Things (IoNT). In Proceedings of the 2015 Internet Technologies and Applications (ITA), Wrexham, UK, 8-11 September 2015; IEEE: Piscataway, NJ, USA, 2015; pp. 219-224. 
107. Internet of Everything (IoE): Top 10 Insights from Cisco's IoE Value at Stake Analysis for the Public Sector. 2013. Available online: http://www.cisco.com/web/about/ac79/docs/IoE/IoE-VAS_Public-Sector_Top-10Insights.pdf (accessed on 17 October 2020).

108. Japan, G. New Economic Policy Package; 2017. Available online: https://www5.cao.go.jp/keizai1/package/ 20171208_package_en.pdf (accessed on 17 October 2020).

109. Zobel, A.K.; Hagedoorn, J. Implications of open innovation for organizational boundaries and the governance of contractual relations. Acad. Manag. Perspect. 2020, 34, 400-423. [CrossRef]

110. Abbate, T.; Codini, A.P.; Aquilani, B. Knowledge co-creation in open innovation digital platforms: Processes, tools and services. J. Bus. Ind. Mark. 2019, 34, 1434-1447. [CrossRef]

111. Schaffers, H.; Komninos, N.; Pallot, M.; Trousse, B.; Nilsson, M.; Oliveira, A. Smart cities and the future internet: Towards cooperation frameworks for open innovation. In The Future Internet Assembly; Springer: Berlin/Heidelberg, Germany, 2011; pp. 431-446.

112. Santoro, G.; Ferraris, A.; Giacosa, E.; Giovando, G. How SMEs engage in open innovation: A survey. J. Knowl. Econ. 2018, 9, 561-574. [CrossRef]

113. Yun, J.; Lee, D.; Ahn, H.; Park, K.; Yigitcanlar, T. Not deep learning but autonomous learning of open innovation for sustainable artificial intelligence. Sustainability 2016, 8, 797. [CrossRef]

114. Gidhagen, M.; Helkkula, A.; Löbler, H.; Jonas, J.; Sörhammar, D.; Tronvoll, B. Human-to-nonhuman value cocreation and resource integration: Parasocial actors in a service ecosystem. In Proceedings of the 2017 Naples Forum on Service, Naples, Italy, 6-9 June 2017.

115. Mejtoft, T. Internet of things and co-creation of value. In Proceedings of the 2011 International Conference on Internet of Things and 4th International Conference on Cyber, Physical and Social Computing, Dalian, China, 19-22 October 2011; IEEE: Piscataway, NJ, USA, 2011; pp. 672-677.

116. Chesbrough, H.; Crowther, A.K. Beyond high tech: Early adopters of open innovation in other industries. RED Manag. 2006, 36, 229-236.

117. Schroll, A.; Mild, A. Open innovation modes and the role of internal R\&D. Eur. J. Innov. Manag. 2011, 14, 475-495.

118. Michelino, F.; Caputo, M.; Cammarano, A.; Lamberti, E. Inbound and outbound open innovation: Organization and performances. J. Technol. Manag. Innov. 2014, 9, 65-82. [CrossRef]

119. Casadesus-Masanell, R.; Almirall, E. Open versus closed innovation: A model of discovery and divergence. Acad. Manag. Rev. 2010, 35, 27-47.

120. McAfee, A.; Brynjolfsson, E.; Davenport, T.H.; Patil, D.J.; Barton, D. Big data: The management revolution. Harv. Bus. Rev. 2012, 90, 60-68.

Publisher's Note: MDPI stays neutral with regard to jurisdictional claims in published maps and institutional affiliations.

(C) 2020 by the authors. Licensee MDPI, Basel, Switzerland. This article is an open access article distributed under the terms and conditions of the Creative Commons Attribution (CC BY) license (http://creativecommons.org/licenses/by/4.0/). 